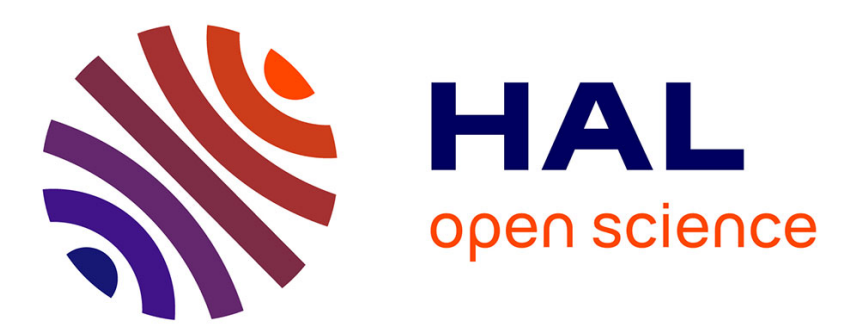

\title{
Cadmium telluride X-ray detectors
}

L.V. Maslova, O.A. Matveev, S.M. Ryvkin, A.I. Terent'Ev, A.K. Khusainov

\section{To cite this version:}

L.V. Maslova, O.A. Matveev, S.M. Ryvkin, A.I. Terent'Ev, A.K. Khusainov. Cadmium telluride X-ray detectors. Revue de Physique Appliquée, 1977, 12 (2), pp.291-292. 10.1051/rphysap:01977001202029100 . jpa-00244160

\section{HAL Id: jpa-00244160 https://hal.science/jpa-00244160}

Submitted on 1 Jan 1977

HAL is a multi-disciplinary open access archive for the deposit and dissemination of scientific research documents, whether they are published or not. The documents may come from teaching and research institutions in France or abroad, or from public or private research centers.
L'archive ouverte pluridisciplinaire HAL, est destinée au dépôt et à la diffusion de documents scientifiques de niveau recherche, publiés ou non, émanant des établissements d'enseignement et de recherche français ou étrangers, des laboratoires publics ou privés. 


\title{
CADMIUM TELLURIDE X-RAY DETECTORS
}

\author{
L. V. MASLOVA, O. A. MATVEEV, S. M. RYVKIN, A. I. TERENT'EV \\ and A. K. KHUSAINOV
}

Ioffe Physical Technical Institute Leningrad, USSR

\begin{abstract}
Résumé. - Dans une première partie de ce travail on a calculé la résolution en énergie de spectromètres $X$ à base de tellurure de cadmium pour une gamme d'énergie s'étendant de 5 à $100 \mathrm{keV}$, en supposant une structure de compteur plane et un champ uniforme. Puis on a comparé les performances réelles de ces compteurs à celles calculées. Les écarts observés sont discutés.
\end{abstract}

\begin{abstract}
First, the energy resolution of CdTe X-ray counters of planar shape is calculated in the energy range $5-100 \mathrm{keV}$, assuming a constant field within the detector. Then, the experimental performance of the counters are compared to the calculations and the discrepancies are discussed.
\end{abstract}

The energy resolution of a solid state detector can be expressed by a sum of several terms, including electronic noise, statistical fluctuations in the pair production and charge collection efficiency. Due to large difference in the electron and hole mobility in cadmium telluride, this material is substantially dependent on the latter parameter. Consequently, the pulse amplitude and resolution varies in the detector, depending on the point of interaction of the radiation in the depletion zone with respect to the electrodes.

Here, we have calculated the importance of peak broadening due to incomplete charge collection in the case of a monoenergetic parrallel photon beam entering a planar counter through the negative electrode. The calculation has been carried out according

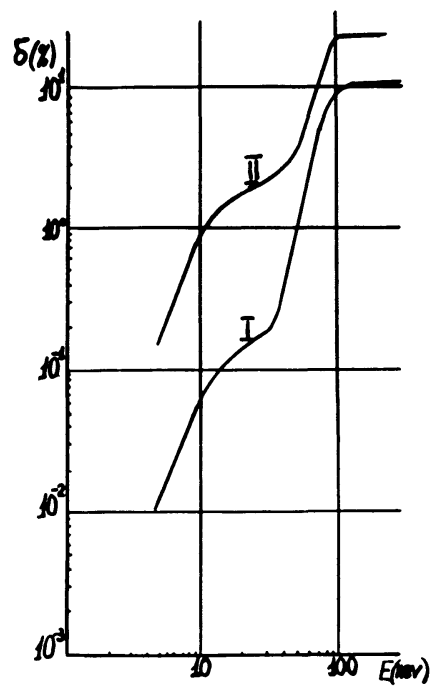

FIG. 1. to the model Zulliger [1] developped previously for $\mathrm{Si}(\mathrm{Li})$ and $\mathrm{Ge}(\mathrm{Li})$ detectors. Since the $\mu \tau$ product in our crystals range between $1-6 \times 10^{-4} \mathrm{~cm}^{2} / V$ for holes and $2-3 \times 10^{-3} \mathrm{~cm}^{2} / \mathrm{V}$ for electrons [2], various fealistic values for the electrons $\left(\lambda_{e}\right)$ and holes $\left(\lambda_{h}\right)$ drift lengths have been considered. Typical results are summarizd on figure 1 . In view of these results, it appears that cadmium telluride planar detectors should give energy resolutions of about $1 \%$ at $60 \mathrm{keV}$ when only the charge collection factor is considered.

However, it appeared in real detectors that the resolution (FWHM) is much larger than expected from the calculations. For example, figure 2 shows the $\gamma$-and X-ray spectra of ${ }^{109} \mathrm{Cd}$ and ${ }^{241} \mathrm{Am}$ obtained with a $20 \mathrm{~mm}^{2}$ counter of $2 \mathrm{~mm}$ thickness, biased at $200 \mathrm{~V}$, in which $\lambda_{\mathrm{e}}=2 \mathrm{~cm}$ and $\lambda_{\mathrm{h}}=0.2 \mathrm{~cm}$. It appears that, even at low energy, the $F W H M$ is noticeally larger than the pulser width, i. e. the fluctuations of the collected charge increases substantially the spectral line.

Furthermore, by changing the applied voltage on the detector, it is clear that the resolution is pratically independent on the charge collection efficiency $\eta$ (Fig. 3), even when the latter approaches $100 \%$. It should be noted that this result is rather unexpected, since in germanium and silicon counters, resolution $\delta$ and charge collection are directly correlated by a relationship in the form $\delta(F W H M)=A(1-\eta)$, where $A$ is a constant $[3,4]$.

These experimental results indicate that the amplitude distribution we obtained for low energy photons, absorbed in a cadmium telluride detector cannot be determined by the factor we calculated, namely the geometric effect due to the difference in electron and 


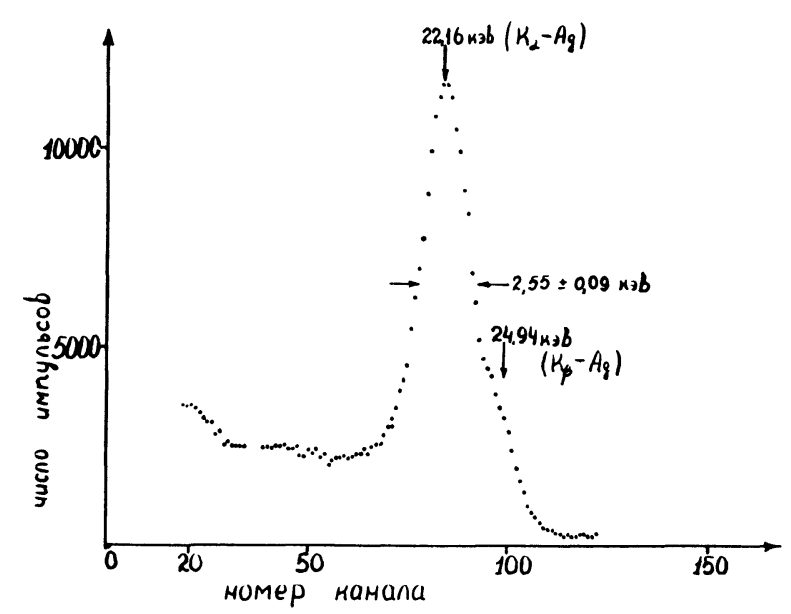

FIG. $2 a$

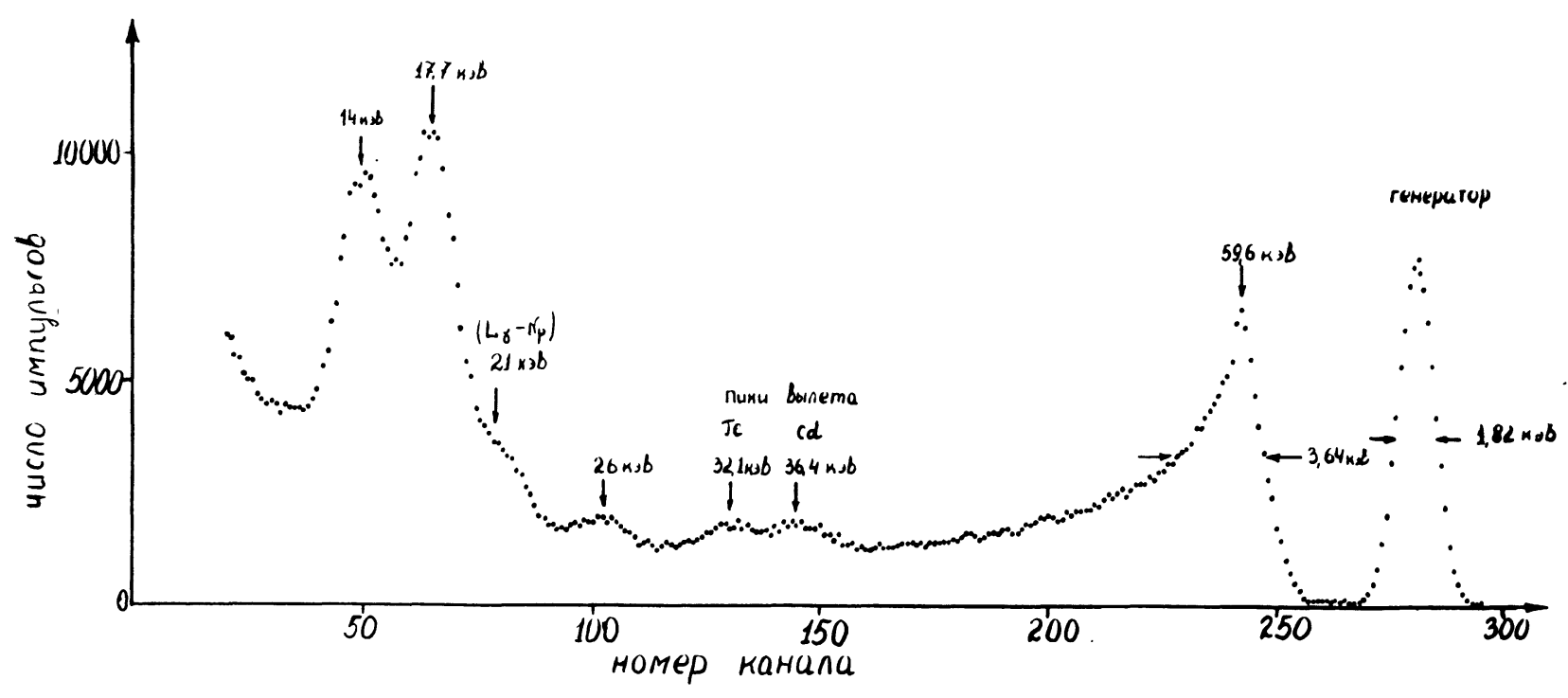

FIG. $2 b$

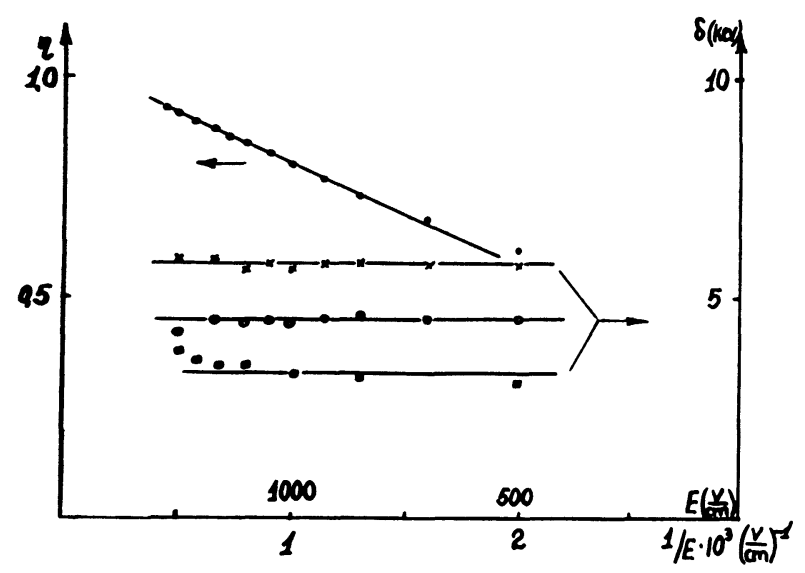

FIG. 3. hole drift length [1]. Statistical fluctuations in pair generation and trapping [3,4] have also to be ruled out. We suggest that the observed anomalous phenomena may be caused by the fact that losses of charges occur at some microdistorsions in the crystal lattice. The shape and size of these defects change with the applied field. Therefore, the enhancement of the $\mu \tau$ product is not a sufficiant goal in the research in improving the $\mathrm{CdTe}$ detectors performance, but further perfection of the crystals is necessary before good spectroscopic results can be achieved with larger area counters. However, in smaller devices, in which the microdistorsions are less pronounced, present better properties. Smaller counters may be useful in solving the problem of elementary analysis. 